\title{
Kerajinan Payung Cukup dan Payung Lunas di Desa Bukian Payangan Gianyar
}

\author{
I Made Suparta ${ }^{1}$, I Nyoman Suardina ${ }^{2}$, I Wayan Mudra ${ }^{3}$
}

1,2. Program Studi Kriya Minat Kayu FSRD Institut Seni Indonesia Denpasar

3. Program Studi Kriya Minat Keramik FSRD Institut Seni Indonesia Denpasar

wayanmudra@isi-dps.ac.id

Kecamatan Payangan terdiri dari 9 desa memiliki sumber daya alam subur serta potensi seni yang patut dikembangkan. Payung cukup dan lunas memiliki keindahan bentuk yang unik dan nilai ekonomi menjanjikan. Kerajinan yang terdapat di desa Bukian Payangan terbuat dari rangkaian susunan bilah-bilah bambu terlihat alami dan langka. Seiring perkembangan jaman, payung tradisional tidak bertangkai mayoritas digunakan petani dan peternak tidak banyak dikenal kaum melineal. Rangkaian bilah bambu yang tersusunan vertical-horizontal memberi daya tarik tersendiri untuk dilakukan penelusuran lebih lanjut terhadap penomena yang terdapat pada payung Payung cukup maupun payung lunas. Penelitian ini menggunakan metode porposive sampling, Validitas data lapangan maupun pustaka didasarkan pada metode ilmiah, pengumpulan dan analisis data serta alat ukur yang digunakan. Kompilasi dan tabulasi data dikoreksi dan dikonstruksikan secara logis dan sistematis. Adapun luarannya berupa publikasi ilmiah yang dimuat pada jurnal terakreditasi yaitu Mudra ISI Denpasar atau jurnal Imaji terbitan UNY (Universitas Negeri Yogyakarta). Dan bahan ajar. Target capaian penelitian ini untuk mengetahui pengertian payung cukup dan lunas, bahan dasar, dan keberlanjutannya.

Kata kunci: kerajinan, payung, cukup, lunas, dan payangan. 


\section{PENDAHULUAN}

Kecamatan Payangan terkenal sebagai penghasil buah leci terbaik di Bali dan memiliki sejarah kerajinan yang yang patut diunggulkan. Eksistensi tersebut dapat dilihat dari dokumen naskahnaskah karya sastra yang berbentuk geguritan, pupuh/tembang dan lukisan Cekorde Rai Payangan (almarhun) yang tersimpan dan terawat dengan baik di puri dangin peken Payangan. Tahun 1940 para pegiat seni payangan telah berpartisipasi aktif berpameran di kota Gianyar bersama seniman Gianyar lainnya. Karya yang berjudul "pemutaran gunung mendaragiri" karya Cekorde Rai Payangan mendapat apresiasi yang positif dari para pengunjung karena keunikannya, kata Cokorde Raka Dherana mantan Bupati Gianyar ketika membuka pameran dan pelantikan pengurus Sanggar Seni Rupa "Giri Kusuma” tgl. 12 Agustus 1987 di gedung serba guna Payangan (Bali Post, 13 Agustus 1987, Hal: 8).

Kerjasama Institut Seni Indonesia Denpasar dengan Dinas Perindustrian dan Perdagangan kabupaten Gianyar dalam pemetaan kerajinan menemukan kuantitas perajin Payangan menempati urutan paling bawah dari 7 (tujuh) kecamatan yang ada di kabupaten Gianyar (Tim Pemetaan. 2019: 31).

Payung Cukup dan Payung Lunas sebagai salah satu kerajinan yang menggunakan bahan dasar bambu memiliki nilai ekonomis yang menjanjikan. Kerajinan yang terdapat di Banjar Subilang, desa Bukian Payangan mayoritas digunakan para penggembala ternak dan petani. Bentuk melengkung mendongak dan bagian bawah dirangkai dari susunan bilahbilah bambu yang melebar adalah daya tarik yang menarik untuk diperhatikan.

Seiring perkembangan jaman dan kepariwisataan khususnya di Payangan, payung jenis ini dibuat dengan ukuran lebih kecil sebagai interior hotel maupun villa (wawancara dengan I Nyoman Teker, 23 Agustus 2020). Pada sisi lain, payung tradisional tidak bertangkai sarat dengan nilai guna ini belum banyak dikenal kaum melinial. Adapun fokus permasalahan yang terkait dengan penelitian ini adalah pengertian payung cukup dan payung lunas, jenis rumpun bambu yang digunakan dan keadaannya saat ini. Payung cukup dan payung lunas sebagai alat pelindung dari paparan sinar matahari dan hujan digunakan dengan cara dijunjung karena tidak bertangkai. Jenis rumpun bambu tali merupakan pilihan perajin sebagai bahan dasar pembuatan payung.

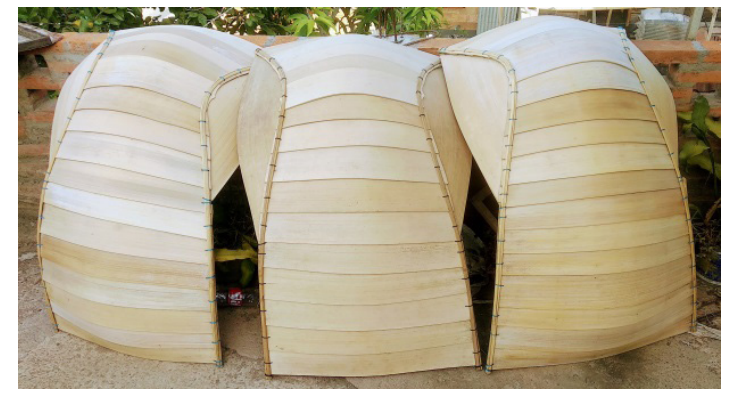

Gambar 1. Payung Cukup (Sumber: dokumentasi penulis)

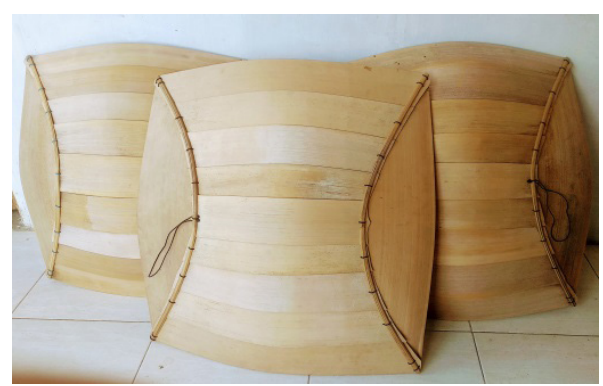

Gambar 2. Payung Lunas. (Sumber: dokumentasi penulis)

Minimnya perajin payung dan "menjauhnya" kaum melinial sebagai perajin payung di desa Bukian adalah awal kecemasan akan punahnya salah satu jenis kerajinan bambu yang ada di Payangan karena kerajinan yang menekankan pada keterampilan tangan itu tidak lagi dibutuhkan para petani dan peternak di saat beraktivitas.

\section{TINJAUAN PUSTAKA}

Kriya yang lebih dikenal dengan istilah kerajinan kalau dilihat dari segi fungsi lebih banyak berorientasi pada tingkat kebutuhan praktisnya, oleh karena itu nilainya dapat bermacam-macam seperti: religius, spiritual, moral, etis, estetis, dan nilai praktis. Berdasarkan fungsinya seni kriya atau kerajinan dapat dibedakan menjadi tiga. Pertama yang tergolong kriya seni sebagai media tersalurnya gagasan estetik, kedua yang tergolong kriya fungsional sebagai sarana pemenuhan kebutuhan hidup sekaligus mengandung elemen estetis, dan ketiga yang tergolong kriya fungsional konstruktif sebagai merupakan simbolisasi dan perwujudan cita-cita luhur (SP. Gustami, 1983/1984: 2-4). Terkait dengan nilai yang mempunyai pengertian "berguna", Karna Yudibrata menjelaskan 4 (empat) nilai landasan dasar antara lain: 1. Agama, 2. Logika, 3. Etika, dan 4. Estetika. Melalui agama akan keluar nilai relegius, magis, kepercayaan dan spiritual. Melalui logika akan keluar nilai intelektual, ilmiah, 
ilmu pengetahuan, dan kebenaran empiris. Melalui etika akan keluar berbagai macam nilai moral, sopan santun, susila dan etis. Melalui estetika akan melahirkan nilai keindahan, keseimbangan, kesegaran, hiburan, keanggunan, keagungan, dan estetis (Karna Yudibrata, 1981/1982: 56-57). Walaupun teori ini ditulis sudah puluhan tahun, peneliti merasa masih layak dijadikan referensi karena obyek penelitian ada relevansinya terkait dengan nilai keindahan. Kompetensi, kualivikasi dan profesionalisme menggali kekayaan produk kriya dengan berbagai tujuan pengembngannya seperti: fungsi, dimensi dan memodifikasi adalah cara agar kriya tetap berkembang. Eksistensi kriya/ kerajinan yang diharapkan berpeluang dan dapat mengatasi tantangan harus dilihat dari dua sisi. Sebagai entitas yang berimplikasi pada pewarisan nilai-nilai kebudayaan tradisi (local genius), dan sisi lainnya dalam kancah berbagai fenomena modern (Anas,Barinul, 2007: 8). I Made Bandem dalam sekapur sirih bukunya SP. Gustami yang berjudul Butir-Butir Mutiara Estetika Timur mengatakan, kriya (craft) berarti energi atau kekuatan yang kemudian diartikan sebagai keterampilan yang dikaitkan dengan profesi. Kerajinan memerlukan keterampilan produksi untuk pemenuhan barangbarang fungsional. Sebuah karya keterampilan kalau dikerjakan dengan baik, ada kesempatan untuk mengalami dan menikmati sebagai karya seni (murni) (Bandem, I Made, 2007: xi). Kreativitas yang inovatif sebagai antisipasi perubahan di masa mendatang menjadi tanggung jawab para pelaku untuk mengembangkan kerajinan perlu dipacu sesuai dengan tuntutan masyarakat. Generasi penerus diharapkan mencari dan berupaya membuat karya kerajinan baru sesuai keperluan dengan jiwa zamannya (Hoop, Van der, 1949, pp. 100-106). Keberlanjutan payung cukup dan payung lunas di desa Bukian sebagai produk kerajinan tangan yang sebelumnya menjadi kebutuhan masyarakat petani dan peternak tidak terlepas dari situasi dan kondisi jaman. Kemajuan teknologi begitu cepat merubah kebutuhan dasar manusia dan meninggalkan produk unggulan kerajinan lokal yang natural dan ramah lingkungan.

Ada dua bentuk payung yang berkembang di masyarakat yaitu bentuk bertangkai dan tidak bertangkai. Penggunaan payuang bertangkai dengan memegang tangkai payung, sedangkan yang tidak bertangkai dilakukan dengan menjunjung/ meletakkan payung di atas kepala. Sumber tertulis yang dijadikan referensi atau pustaka dalam penelitian ini belum ada yang menyinggung tentang payung yang tidak bertangkai secara jelas. Dalam Kamus Besar Bahasa Indonesia disebutkan bahwa kata payung mengandung arti alat sebagai pelindung badan supaya jangan kena panas matahari atau kena hujan, biasanya dibuat dari kain atau kertas diberi bertangkai dan dapat dilipa-lipat, dan juga yang dipakai sebagai tanda kebesaran ( Tim, 1989: 656). Kamus Bahasa Bali Indonesia, kata payung mengandung pengertian hampir sama dengan pajeng: 1 payung; 2 topi. Juga kata pajeng mengandung pengertian payung. Jadi kedua kata tersebut mempunyai arti yang sama. Sedangkan kata topi sama-sama berfungsi sebagai pelindung paparan matahari dan hujan namun tidak bertangkai dan melindungi pada bagian kepala. (Tim Penyusun. 2016 : 512). Arti payung sebagai benda bertangkai yang berfungsi melindungi badan dari paparan matahari dan hujan juga disebutkan dalam wikifedia. Payung adalah suatu benda pegang yang digunakan untuk mencegah hujan mengguyur tubuh seseorang. Juga digunakan untuk menciptakan bayang-bayang dan mencegah terpaparnya orang oleh sinar matahari. Payung juga digunakan untuk menahan cahaya matahari disebut parasol. (http:// id.m.wikipedia. Tanggal 20 April 2020). Beberapa pengertian payung yang telah disebutkan di atas belum menyiratkan adanya cara pemakaian payung dengan cara dijunjung. Junjung dalam Kamus Besar Bahasa Indonesia disebutkan membawa di atas kepala (Tim Penyusun. 1989 : 369).

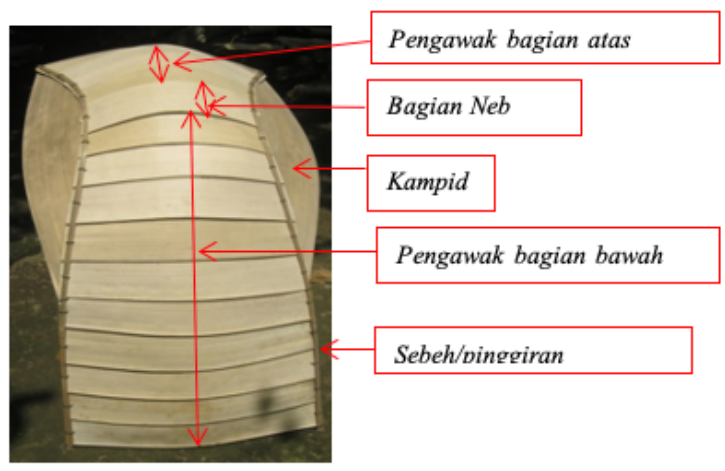

Gambar 3. Bagian-bagian Payung Cukup.

(Sumber: dokumentasi penulis) 


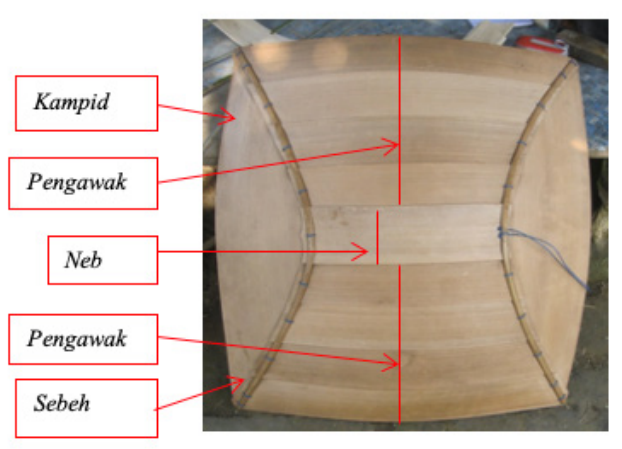

Gambar 4. Bagian-bagian Payung Lunas.

(Sumber: dokumentasi penulis)

Kata lunas dalam Kamus Jawa Kuna (Kawi) Indonesia mempunyai arti; 1. berarti payung (pajeng), 2. perahu (L. Mardiwarsito. 1986: 326). Sedangkan pada Kamus Bahasa Bali Indonesia kata lunas berarti; tiang pada jukung/perahu. (Tim Penyusun. 2016: 446). Perahu maupun jukung menunjukkan pada benda yang berbeda penggerak dan ukuran, namun ada kesamaan fungsi dan kemiripan bentuk. Kata Cukup dalam kamus bali indonesia berarti kuncup, cukupang = kuncupkan (Tim Penyusun. 2016: 172). Cukupang adalah kata kerja yang digunakan untuk mengkuncupkan pajeng atau payung yang merupakan salah satu sarana upacara agama hindu. Bambu adalah Tumbuhan berakar serabut yang batangnya beruas-ruas, keras dan tingginya menyerupai pohon besar. Bambu betung/petung, duri, kuning, dan bambu tali (Tim, 1989: 74). Di Bali bambu disebut tiying yang rumpunnya cukup beragam dan nama-namanya disesuaikan dengan warna maupun kegunaannya. Maanfat dan keuletan jenis bamboo sebagai bahan kerajinan juga diungkapkan oleh G. Margono dalam Tesisnya Ardana Dewa Putu, Bambu tumbuhan sebangsa rumput yang cocok untuk bahan anyaman. Adapun jenis rumpum bambu tersebut seperti bambu tali, betung, gembong, kadalan dan bambu ori (Ardana, Dewa Putu,2013: 9).

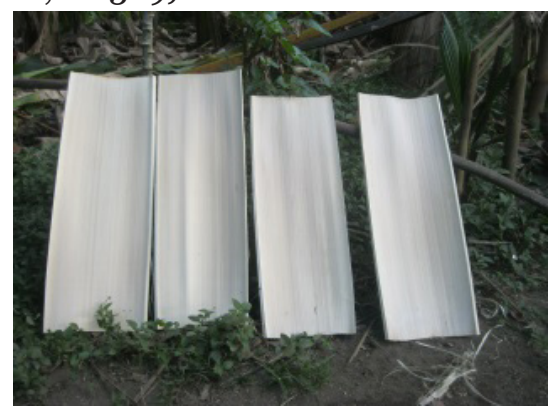

Gambar 5. Bilah Bambu. (Sumber: dokumentasi penulis)

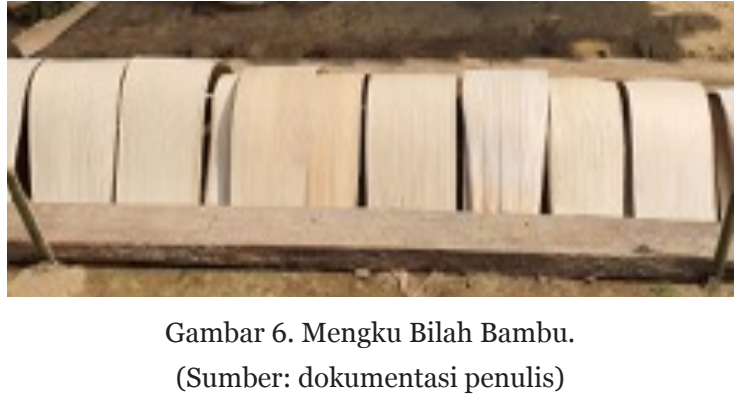

Bambu sebagai salah satu bahan pokok kerajinan tangan maupun konstruksi bangunan telah digunakan manusia sejak beberapa abad yang lalu. Sifat lentur, ulet, dan multi fungsi bambu adalah pilihan tepat para perajin untuk dijadikan bahan kerajinan. Buku tentang rebung yang ditulis Winarno, F.G. menceriterakan; pada tahun 1867 kerajinan bambu jenis topi dari Tangerang Jawa barat sudah terkenal di seluruh dunia khususnya Prancis dan Amerika. Sekitar tahun 1880 topi berbahan bambu hasil perajinan Serdang, Nempang , Rejang dan Tjilongkong sudah sangat populer dan mulai diekspor (Winarno, F. G. 1992: 17). Disini menunjukkan bambu sebagai bahan dasar kerajinan topi dengan teknik anyam telah dikenal perajin bambu sejak dua abad yang silam.

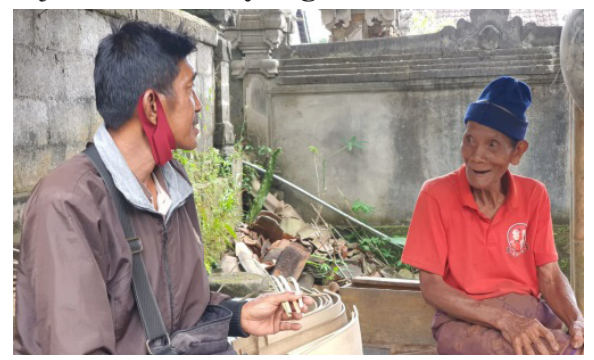

Gambar 7. Wawancara dengan perajin Payung I Nyoman Teker. (Sumber: dokumentasi penulis)

\section{METODE}

Penelitian ini dilaksanakan dalam upaya pendataan sekaligus inventarisasi produk budaya lokal yang ditinggalkan masyarakat pendudungnya, sehingga diperlukan upaya penyelamatan agar kerajinan yang terikat erat dengan kehidupan masyarakat agraris itu terdokumentasikan secara baik. Begitu juga untuk membuktikan kebenaran data yang diperoleh di lapangan ataupun lewat kepustakaan. Pembuktian tersebut didasarkan pada metode serta kaidahkaidah ilmiah dengan memperhatikan aspek populasi dan sampel, metode pengumpulan data, analisis data serta alat ukur yang digunakan. Batasan-batasan secara spesifik, yakni mengidentivikasi bahan, proses 
pembuatan serta bentuk payung cukup dan payung lunas.

Metode porposive sampling digunakan untuk pemilihan dan penentuan populasi dan sampel yang dapat mewakili setiap variabel produk kerajinan payung cukup dan payung lunas di desa bukian Payangan. (Hadi, Sutrisno, 1986: 27). Kompilasi atau kumpulan yang tersusun secara teratur akan didapatkan pada tahap penjajagan penelitian lewat survey lapangan dan kepustakaan. Tabulasi data diharapkan untuk memudahkan pengamatan dan evaluasi terhadap hasil surve tentang keberadaan perajin maupunjenis produk payung yang dihasilkan. (Masri Singarimbun, 1989:12). Sumber pokok data penelitian ini didapatkan dari perajin bapak Teker yang beralamat di Br. Sebilang dan I Made Krisna pegawai Perbekel desa Bukian kecamatan Payangan Gianyar.

Presedur penelitian disusun secara sistemastis dan kronologis dengan 3 (tiga) tahapan yang sebelumnya telah dilakukan seperti: 1 . pemetaan kerajinan di daerah Gianyar pada tahun 2018. Pemetaan tersebut dilakukan terkait dengan persiapan Disperindag kabupaten Gianyar menjadi kota kerajinan Dunia. 2. Mencari informasi lanjutan di kantor/stap kantor Perbekel Bukian tentang jenis kerajinan yang tercatat secara administrasi/formal. 3. Mengunjungi rumah perajin payung cukup dan payang lunas untuk mendapatkan informasi langsung tentang keberadaan produk yang dibuat seperti: bahan baku dasar, tahapan proses pengerjaan dan keberlanjutan perajin yang membuat payung cukup dan payang lunas.

Referensi, data lapangan, dan hasil wawancara/ interview ditabulasi dan dinarasikan sebagai penjelasan terhadap payung cukup dan payung lunas sesuai dokumentasi foto yang ada. Studi pustaka atau referensi juga menggunakan hasil penelitian I Made Berata yang berjudul Pengawin Sebagai Sarana Upacara Agama Hindu Bali. Judul ini ada korelasinya dengan obyek yang diteli khususnya tentang payung.

Instrumen yang digunakan dalam Penelitian ini berupa metode wawancara bebas terpimpin.

\section{HASIL DAN PEMBAHASAN}

Dua jenis payung tradisional yang tidak bertangkai ini tdak banyak dikenal oleh kaum melenial, padahal produk kerajinan yang unik dan langka tersebut menjadi andalan pada jamannya. Produk yang langka ini telah lama menghilang dari perhatian masyarakat, sehingga perlu ditelusuri keberadaannya termasuk asal-usulnya. Penelitian ini dilakukan atas dorongan rasa ingin terhadap fenomena sosial yang ada di tengah-tengah masyarakat desa Bukian Payangan khususnya pada perajin payung.

Desa Bukian terdiri dari 11 (sebelas) banjar diantaranya: 1. Banjar Bukian, 2. Banjar Bukian Kaja, 3. Banjar Bukian Kawan, 4. Banjar Lebah A, 5. Banjar Lebah B, 6. Banjar Tiyingan, 7. Banjar Subilang, 8. Banjar Dasong, 9. Banjar Tangkup, 10. Banjar Ulapan, dan 11. Banjar Amo merupakan salah satu desa yang memiliki kerajinan dengan bahan dasar kayu dan bambo yang ada di kecamatan Payangan. Perajin yang ada di desa Bukian dari tahun ke tahun semakin berkurang termasuk perajin payung yang digeluti oleh satu keluarga (Krisna I Made, wawancara : 31 Agustus 2020).

\section{Pengertian Payung Cukup}

Secara harfiah, pengertian Payung Cukup terdiri dari 2 (dua) kata yaitu payung dan cukup. Kedua kata tersebut mengandung makna atau dimaknai secara terpisah berdasarkan arti leksikal yaitu kata Payung mempunyai arti sendiri dan kata cukup juga memiliki arti tersendiri. Lebih lanjut pengertian harfiah disesuaikan dengan kontek dalam penelitian ini khususnya payung cukup merupakan alat pelindung badan dari terik sinar matahari dan hujan ( Tim, 1989: 656).

Payung cukup terbuat dari bilah ruas bambu dengan bentuk cembung segi empat hampir sama sisi yang merupakan hasil rangkaian bilah-bilah bambu yang tersusun secara tindih menindih. Payung Cukup terdiri dari 5 (lima) unsur bagian diantaranya : Neb, pengawak, kampid, sengkulung, dan sebeh (Teker I Nyoman, Wawancara: 23 Agustus 2020). $\mathrm{Neb}$ adalah bilah bambu yang letaknya paling atas dan ukurannya paling pendek yaitu lebar $10 \mathrm{~cm}$. kali panjang $43 \mathrm{~cm}$. Pengawak atau bagian badan 
dari payung cukup adalah susunan bilah bambu yang disusun ke arah atas dan bagian bawah dengan ukuran semakin ke atas maupun kebawah dari neb semakin memanjang. Susunan pengawak yang ke atas terdiri dari 4 (empat) bilah bambu, mulai dari panjangnya $46-62 \mathrm{~cm}$. Sedangkan yang kearah bawah terdiri dari 9 (sembilan) bilah yang panjangnya mulai dari 44 - $62 \mathrm{~cm}$. Adapun lebar setiap bilah bambu baik neb maupun pengawak berkisar antara $7 \mathrm{~cm}$ sampai dengan $10 \mathrm{~cm}$. Lebar ini kalau diukur dari tampak bagian atas payung. Setiap bilah bambu pada bagian neb maupun pengawak disusun atau dirangkai secara horizontal/mendatar.

Kampid atau sayap adalah bagian sisi kiri-kanan neb dan pengawak yang disusun dengan posisi vertical. Ukuran bagian kampid mempunyai ukuran lebih panjang dan lebar dibandingkan dengan ukuran neb maupun pengawak. Panjang atau tinggi sayap ke atas maupun ke bawah dari posisi neb dengan rincian kearah atas 4 (empat) bilah bambu dan arah bawah sebanyak 5 (lima) bilah. Bentuk bilah bambu yang melengkung secara vertical maupun horizontal dibuat dengan cara mengku. Mengku adalah cara melengkungkan bilah bambu dengan cara diblagbag atau dipasung kemudian dijemur dibawah terik sinar matahari.

Selain dijemur, mengeringkan bilah bambu dilakukan dengan cara ngunun atau diunun yaitu cara mengeringkan dengan embusan asap dapur. Blagbag adalah alat yang terbuat dari bamboo atau kayu yang berfungsi untuk menjepit atau menekan sesuatu agar tidak bergerak atau bergeser (Teker I Nyoman, Wawancara: 30 Agustus 2020).

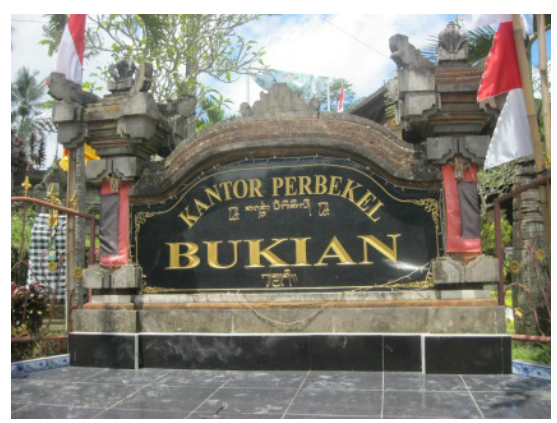

Gambar 8. Kantor Perbekel Desa Bukian. (Sumber: dokumentasi penulis)

Sengkulung yang terletak dibalik bagian dalam payung posisinya tepat berada dibawah neb. Bentuk sengkulung yang setengah opal mempunyai ukuran tidak simetris, dimana pada bagian bawah meruncing dan bagian atas melebar sekitar $13 \mathrm{~cm}$.

Sebeh/pinggiran adalah bagian sisi payung yang terbuat dari iratan atau rautan bambu yang berfungsi sebagai penguat. Adapun bagian yang dikasi Sebeh/ pinggiran adalah bagian kedua sisi kiri kanan pengawak. Sedangkan pada sisi atas dan bawah dibiarkan terlepas bebas. Menurut penuturan I Nyoman Teker maupun istrinya Ni Nyoman Rekin kalau bagian atas dan bawah diisi dengan Sebeh/ pinggiran menjadikan payung akan lebih berat dan cepat rusak karena serat bambu dalam posisi horizontal. Sebeh/pinggiran sebenarnya bisa diisi sesuai dengan pemesannya (Wawancara: 31 Agustus 2020).

Berdasarkan pengamatan dilapangan antara bulan Juli sampai dengan akhir Oktober 2020, tali pengikat Sebeh/pinggiran telah kendor sehingga bentuk dan susunan bilah bambu renggang dan bergeser. Renggang dan bergesernya bilah-bilah bambu dan kendornya tali ikatan sebeh/pinggiran terjadi akibat perakitan bahan bambu dilakukan ketika masih basah. Hal ini dapat merubah bentuk payung menjadi mekiud atau mencong. Perubahan bentuk juga terjadi pada bagian sengkulung menyebabkan ukuran menyusut dan keras sehingga ketika dipakai kepala terasa dijepit.

Di Bali, kata payung juga ditemukan dalam sarana upacara agama hindu yaitu Payung Pagut. Secara visual Payung Pagut ini menyerupai bentuk kerucut terbuat dari anyaman bambu atau lembaran logam, bertangkai dan disangga oleh 4 (empat) canggah wang atau kuda-kuda.

\section{Pengertian Payung Lunas}

Di atas telah disinggung tentang kata lunas yang mempunyai pengertian ganda,; 1. Kata lunas dalam bahasa Indonesia dan Lunas dalam bahasa Bali. Dalam bahasa Indonesia mengandung dua pengertian lagi yaitu : tentang utang-piutang yang berarti terbayar, impas. Lunas juga mengandung arti balok memanjang di dasar perahu (TIm Kamus Besar Bahasa Indonesia, 1989 : 537). Dalam bahasa kamus Bali - Indonesia mempunyai pengertian tiang pada jukung/perahu. Perbedaan antara balok panjang di bawah perahu dengan tiang pada perahu/jukung dapat dikatakan adanya perbedaan arah posisi balok/kayu pada perahu. Satu dengan posisi berdiri/ vertical, satunya lagi dengan posisi terlentang/ 
horizontal. Berbeda dengan kata lunas dalam Kamus Jawa Kuna (Kawi) Indonesia mempunyai arti; 1. berarti payung (pajeng), 2. perahu (L. Mardiwarsito. 1986: 326).

Di Bali sendiri kata pajeng disebut jug dengan istilah tedung maupun ungkulan. Tedung maupun ungkulan adalah payung bertiang yang berfungsi melindungi pretima maupun seseorang yang di hormati agar terhindar dari panasnya sinar matahari dan hujan.

Secara umum payung cukup maupun payung lunas tidak jauh berbeda kalau dilihat dari segi penggunaan bahan, susunan bilah bambu/dan teknik merangkainya. Perbedaan yang tampak adalah pada ukuran dan bentuk sengkulung dan ukuran panjangnya. Untuk mencapai ukuran panjang payung lunas menghabiskan 15 (lima belas) bilah ruas bambu, sedangkan pada payung lunas manghabiskan 9 (Sembilan) bilah ruas bamboo sudah termasuk bilah neb. Lebar bilah bambu untuk kampid lebih lebar dibandingkan dengan bilah neb dan pengawak. Ukuran asli lebar setiap ruas bilah bambu berkisar antara 20cm. sampai dengan 23c. dengan panjang antara $67 \mathrm{~cm}$. sampai dengan $73 \mathrm{~cm}$. Lebar asli setiap ruas bambu yang mencapai $23 \mathrm{~cm}$. dalam pembuatan bilah rata-rata dibagi menjadi dua bilah kecuali bagian kampid/sayap dibiarkan secara utuh.

Posisi sengkulung yang bentuknya bulat melingkar tepat berada ditengah-tengah di balik/babawah posisi dari pada neb dengan garis diameter $18 \mathrm{~cm}$. Adapun tinggi sengkulung bersifat fleksibel dalam artian disesuaikan dengan tinggi dahi pengguna antara $8 \mathrm{~cm}$. sampai $9 \mathrm{~cm}$. Secara visual bentuk payung lunas berupa segi empat sama sisi, namun yang setiap sisi bagian tengahnya dibentuk agak cembung. Bentuk cekung maupun cembung yang ada pada payung cukup maupun payung lunas diperoreh dengan mengiris/meratut kedua ujung sisi kiri-kanan bilah bambu masing-masing sekitar $1 \mathrm{~cm}$. (satu senti meter).

\section{Jenis Alat dan Bahan}

Berkualitasnya suatu produk atau barang yang dibuat sangat ditentukan oleh kelengkapan dan ketepatan pengguanaa peralatan serta keterampilan yang dimiliki seorang perajin/kriyawan. Keterampilan penggunaan alat dan memahami akan sifat-sifat bahan tidak saja berpengaruh pada kualitas yang dihasilkan, juga dapat memaksimalkan jumlah produk yang dibuat. Kepekaan pengolahan bahan oleh perajin bapak Nyoman Teker perlu menjadi perhatian, karena produk yang dihasilkan masih terasa berat saat digunakan. Setelah diadakan pengukuran untuk payung cukup memiliki bobot/ berat $1,600 \mathrm{~kg}$. dan payung lunas $09,60 \mathrm{~kg}$.

\section{Alat \\ Temutik}

Temutik adalak pisau Raut yang memiliki bentuk dan ukuran lebih kecil dari pada pisau yang bagian ujungnya runcing. Pisau ini berfungsi untuk meraut, memotong, melobangi ataupun mengirat bambu. Mata pisau dibuat sebelah/satu sisi agar tidak licin kalau digunakan.

\section{Pusut}

Pusut adalah alat tusuk yang berfungsi untuk melubangi. Ada beberapa jenis bentuk pusut yang digunakan bapak I Wayan Teker untuk mengerjakan payung diantaranya:

Pusut berbentuk bulat lancip pada ujungnya. Pusut ini digunakan untuk melobangi sekaligus mengunci sambungan dalam merangkai bilah ruas bambu.

Pusut Pangleng adalah berbentuk bulat lancip pada bagian badan ada pangleng berupa undakan. Pusut Pangleng mempunyai fungsi utama untuk menakar jarak lubang

\section{Penyelubitan}

Penyelubitan adalah alat yang memiliki bentuk mirip dengan pahat penatar yang biasa digunakan untuk membuat bidang datar pada kedalam tertentu suatu relief/ukiran. Penyelubitan ini memiliki ujungn lancip, tidak pipih seperti pahat penatar. Nyelubit adalah istilah yang dipakai untuk melobangi dan memperbesar hasil lobangan agar lebih mudah memasukkan sesuatu pada lobang. Alat ini juga mirip dengan bentuk pangot yang biasa digunakan membuat cekungan.

\section{Pahat}

Pahat adalah suatu alat yang biasa digunakan oleh tukang dalam melakukan pekerjaan. Fungsi maupun bentuk pahat disesuaikan dengan peruntukannya seperti pahat tukang kayu, tukang ukir, tatah dan pematung. Ketebalan dan bentuk masing-masing pahat tersebut sangat berbeda, seperti pahat yang digunakan perajin payung I Wayan Teker. Jenis 
pakat yang diperlukan adalah pengramcab yaitu pahat yang bentuknya lurus dan bergusi sebelah/ bermata satu. Pahat pengramcab model ini dirancang khusus untuk keperluan nylusuh. Nylusuh adalah memasukkan iratan/rautan tali bambu untuk merangkai bilah ruas bambu.

\section{Gergaji}

Dalam dunia pertukangan ada dua jenis gergaji yang biasa digunakan yaitu gergaji pemotong dan pembelah. Sebagai pembeda fungsi dua alat ini dapat dilihat dari komposisi bentuk matanya. Gergaji pemotong mempunyai komposisi sejajar berjajar, mata runcing simetris (bentuk kerucut), sedangkan gergaji pembelah komposisi mata gergaji sebagian sisi tegak lurus dan sebagian lagi miring, mata runcing tidak simetris (miring tegak lurus).

\section{Bahan}

Pemanfaatan bambu sebagai bahan maupun alat pemehunan kebutuhan rumah tangga telah lama dikenal masyarakat secara luas. Bambu sebagai bahan dasar kerajinan tangan maupun bangunan karena memiliki kelebihan dibandingkan bahan lainnya seperti kelenturannya, keuletan, mudah didapatkan serta harganya relatif murah. Beberapa referensi terkait penggunaan bambu sebagai bahan kerajinan secara mayoritas bambu digunakan sebagai bahan anyaman, kursi dan konstrusi bangunan. Jenis rumpun bambu tali yang mempunyai sifat lentur dan ulet sering dipakai sebagai bahan anyaman topi, besek, keben dan sejenisnya. Bambu apus, santong, petung, tamblang, suwat, tutul dan buluh oleh perajin di jawa barat dan daerah Bona Bali dijadikan bahan utama untuk kerajinan meja, kursi, tempat tidur dan meja rias.

Bambu tali yang sudah lumrah digunakan sebagai bahan kerajinan sebenarnya masih dapat dipilah kembali sesuai tempat dan umur tebangnya. Kondidi tempat dan masa tebang justru menjadi pengetahuan khusus bagi perajin untuk mendapatkan kualitas produk yang memadai. Bapak Teker I Wayan perajin payung asal Banjar Subilang, desa Bukian, Payangan justru banyak belajar dari pengalaman dalam penggunaan bambu tali sebagai bahan payungnya. Bambu tali yang baik untuk bahan payung adalah bambu yang dumele dan tumbuh di pinggir kali/ sungai. Bambu dumele adalah bambu yang tidak tua dan tidak terlau muda. Sebagai tanda bambu dumele adalah awal lepasnya kelopak dari batang bambu. Sedangkan jenis bambu yang baik adalah bambu yang tumbuh di tepi sungai karena memiliki ruas yang lebih panjang.
Sumber data juga didapat secara tidak sengaja dari bapak Sudiarsa I Nyoman dari banjar Ata Batubulan terkait bahan untuk pembuatan payung lunas. Informasi ini sebagai tambahan pengetahuan dan tidak dibahas dalam penelitian ini. Beliau mengatakan; payung lunas juga dibuat dari upih yaitu bagian pangkal pelapah daun pinang (Sudiarsa I Nyoman, Wawancara: Kamis, 20 Agustus 2020).

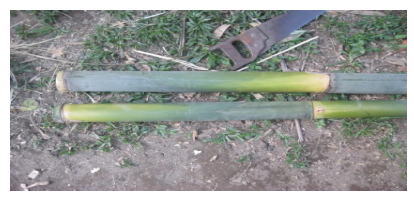

Gambar 9. Bambu dumele (Sumber: dokumentasi penulis)

\section{Proses Pembuatan}

Keterampilan membuat payung cukup dan payung lunas yang ditekuni I Wayan Teker dan istrinya $\mathrm{Ni}$ Nyoman Rekin berawal dari kehidupannya yang sebelumnya sebagai burung tukang gebuang atau menyemai ketela di Kintamani Bangli. Kisah dan pengalaman tersebut sampai sekarang dijadikan patokon tentang tatacara membuat payung payung cukup maupun payung lunas.

Payung cukup dan payung lunas mulai dikerjakan oleh bapak Teker sejak tahun 1952. Beliau belajar bembuat kerajinan payung dilakukan secara tidak langsung di Banjar Awan desa Kintamani kecamatan kintamani Kabupaten Bangli. Keterampilan membuat payung yang digeluti sekarang betulbetul diluar dugaan dan dianggapnya sebagi jalan hidup, karena tujuan awal ia pergi Kintamani untuk menjadi buruh kebun. Lebih lanjut diceriterakan bapak Teker, di Kintamani beliau menjadi buruh tukang gebuang ketela tepatnya di di Banjar Awan desa Kintamani yang jaraknya sekitar $20 \mathrm{Km}$. dari desa Bukian Payangan. Karena jaraknya cukup jauh, bapak Teker memutuskan untuk memondok di desa tersebut. Saat itu desa Kintamani terkenal dengan penghasil pala bungkah (umbi-umbian), pala wija (kacang-kacangan) dan pala gantung (buahbuahan). Kesuburan lahan perkebunan di Kintamani mampu mengundang para buruh pondokan dari berbagai belahan desa di Bali. Buruh pondokan adalah buruh yang tinggal di sebuah rumah yang berada dikebun, dibuat secara sederhana dan bersifat sementara. Pondok dapat diartikan rumah yang berada di kebun.

Waktu istirahat para buruh pondokan mengisi waktu luangnya dengan membuat payung seperti yang dilakukan penghuni pondokan disebelahnya. 
Keakraban antara buruh pondokan menjadikan bapak Teker dapat kesempatan secara diam-diam melihat cara-cara tetangganya membuat payung. Anehnya orang yang mengerjakan payung "gurunya" sampai sampai sekarang tidak diketahui nama maupun alamatnya. Keterampilan membuat payung yang didapat saat menjadi buruh ngebuang di Br. Awan Kintamani itu sampai sekarang masih dilakoninya.

\section{Pengupasan Bambu}

Mencari dan mengumpulan bambu terpilih adalah langkah awal bagi I Wayan Teker untuk mulai pekerjaaannya membuat payung. Bambu dipotong ruas demi ruas dan bembuang soca (batasan ruas). Kulit bambu dikupas/diraut dan dibiarkan sekitar satu centi meter. Dibagian tengah kulit bambu yang tersisa itulah nantinya dijadikan posisi/tempat untuk membelah bambu. Maksud pembiaran kulit bambu tersebut agar bambu tidak pecah dan menggulung kalau dijemur.

\section{Mengku}

Setelah dikupas bambu kemudian dibengku dan dijemur menggunakan sebuah alat yang disebut blagbag. Alat pres tradisional ini berfungsi untuk membentuk bilah-bilah ruas bambu tetap melengkung sesuai dengan kebutuhan bentuk payung. Waktu yang dibutuhkan untuk mengku selama 3-5 (tiga sampai lima) hari dalam keadaan matahari bersinar normal.

\section{Merongga}

Tahap selanjutnya melobangi dengan teknik slubit adalah membuat rongga pada bilah bambu dengan memasukkan dan menekan kebawah pangkal pusut untuk membuat rongga menjadi renggang dan mudah memasukkan tali dii). Merongga dilakukan berlawanan dengan arah serat bambu. Perangkaian bilah bambu menggunakan 4 (empat) buah dii yaitu iratan tali bambu yang selebar $1 \mathrm{~cm}$. (satu senti meter). Satu buah payung masing-masing menggunakan 4 (empat) buah tali dii. Tali dii dibuat dengan menggunakan bagian kulit bambu agar lebih kuat dan lebih mudah memasukkan pada rongga.

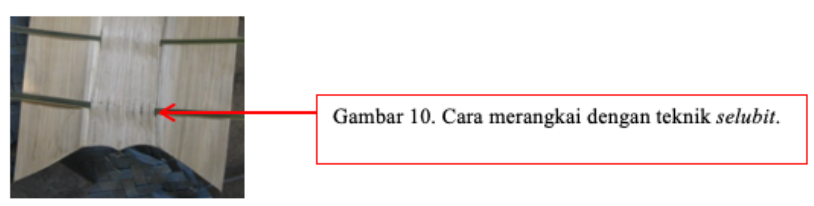

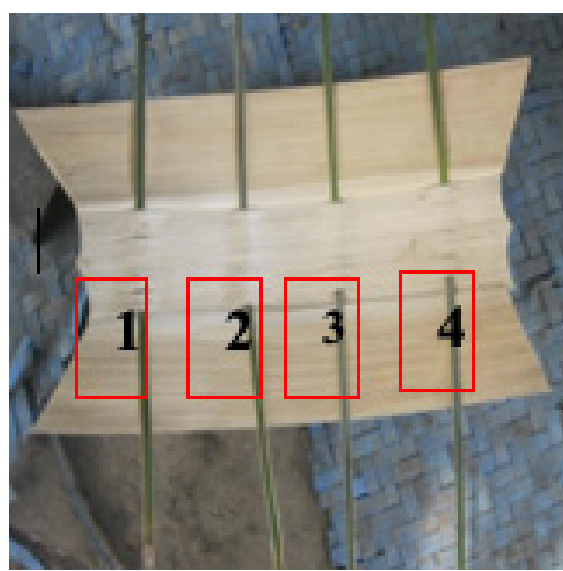

Gambar 11. 4 (empat) buah dii pada neb (Sumber: dokumentasi penulis)

\section{Merangkai}

Merangkai adalah tahapan penyusunan biah ruas bambuyang dilakukan secara berurutan. Perangkaian diawali dari bagian bilah neb sebagai pokok atau patokan untuk merangkai selanjutnya. Neb menempati posisi bilah paling atas disusul/disisipi bilah di bawah kiri-kanan atau atas-bawahnya secara berurutan. Kearah atas sebanyak 4 (empat) bilah dan ke bawah sejumlah 9 (sembilan) bilah untuk payung cukup dan 4 (empat) bilah ke atas, 4 (empat) bilah ke arah bawah untuk payung lunas . (Lihat gambar no. 5).

Setelah merangkai bagian neb dan pengawak dilanjutkan pemasangan kampid/sayap sekaligus pemasangan sebeh/pinggiran. Pemasangan sebeh atau pinggiran hanya pada sisi kiri - kanan neb dan pengawak sekaligus berfungsi menjepit bagian pangkal sayap. Menurut bapak Teker, sebeh/ pinggiran menggunakan tali plastik, karena tali ijuk sudah sangat langka dan kalaupun ada kualitasnya kurang bagus.

Pemasangan sengkulung merupakan tahapan pekerjaan paling akhir dalam pembuatan payung cukup maupun payung lunas. Bapak Teker I Wayan belum pernah menggunakan bahan pelapis atau cat seperti: pernis, moilek, paragon atau cat pewarna lainnya untuk payungnya.

\section{Kondisi Kerajinan}

Desa Bukian terletak diujung timur kecamatan Payangan. Padat tahun 1990 di desa Bukian berkembang beberapa jenis kerajinan tangan berbahan dasar kayu dan bambu. Patung jerapah, 
pohon pisang, kelapa dan bunga anggrek adalah jenis kerajinan andalan penopang ekonomi keluarga. Seiring perjalanan waktu, kedua jenis kerajinan tersebut memudar bahkan tidak berproduksi lagi. Berdasarkan penjelasan stap perbekel Bukian dan beberapa perajin di banjar Lebah dan banjar Subilang, para perajin yang dulu menekuni kerajinan kayu sekarang menjadi buruh sawah seperti: mencangkul, panen dan menanam padi. Sedikit yang masih menekuni kerajinan kayu dan bambu. Kerajinan bambu yang masih berlanjut di desa Bukian seperti menganyam keranjang suci, sangkar ayam dan kise.

Khusus kerajinan payung yang digeluti bapak Teker juga sebagai sampingan dan kalau ada pesanan. Beliau tidak berani memproduksi dan menyetok payung khususnya payung cukup, takut kalau tidak ada yang membeli. Saat ini sebuah payung cukup digargai Rp. 250.000 (dua ratus lima puluh ribu rupiah) dan payung lunas seharga Rp. 100.000 (seratus ribu rupiah). Kondisi ini sangat memprihatinkan dan dicemaskan bapak Teker karena sekarang generasi penerusnya tidak berminat menekuni kerajinan payung yang semakin langka.

\section{SIMPULAN DAN SARAN}

\section{Simpulan}

Hasil akhir sebuah penelitian untuk mendapatkan sebuah jawaban dari permasalahan yang diajukan atau ditemukan untuk dicarikan solusi dan berdaya guna bagi masyarakat. Adapun jawaban yang didapat terkait penelitian produk kerajinan payung cukup dan payung lunas di Desa Bukian Payangan Gianyar adalah sebagai berikut:

Payung dan adalah alat pelindung dari paparan sinar matahari dan hujan yang dijunjung dan terbentuk dari rangkaian bilah-bilah bambu tersusun secara tindih menindih. Payung cukup bagian depan menjolok mendongak dan bagian bawah terjuntai cenderung memberi perlindungan lebih pengguna (peternak) dari paparan sinar matahari dan hujan. Payung lunas berbentuk segi empat "opal" sebuah kecenderungan "dirancangguna" untuk para petani pemikul maupun penjungjung agar luput dari paparan sinar matahari dan hujan.

Rumpun jenis bambu tali sedang dumele yang di bantaran sungai atau di pinggir kali merupakan pilihan tepat sebagai bahan kerajinan payung cukup dan payung lunas.
Kerajinan payung di desa Bukian mengalami kesulitan bangkit dan berkembang karena telah ditinggalkan masyarakat petani dan peternak serta tidak normalnya perkembangan pariwisata di Bali saat ini. Generasi muda sangat enggan menjadi perajin payung dan memilih sebagai tukang cangkul, memanen dan menanam padi.

\section{Saran}

Agar kerajinan payung yang ada di Desa Bukian Payangan bisa menggeliat kembali hendaknya ada sinergi antara Bumdes dengan instansi terkait untuk mempasilitasi produk yang dibuat perajin dapat tersalurkan. Generasi melineal sedini mungkin diberi pemahaman tentang pentingnya arti pelestarian terhadap pewarisan benda-benda kerajinan yang telah ada sebelumnya. ISI Denpasar sebagai lembaga pendidikan tinggi seni yang melaksanakan Tri Dharmanya untuk berperan lebih aktif di tengah masyarakat yang membutuhkan.

\section{DAFTAR RUJUKAN}

Anas, Barinul, (2007), "Pendidikan Tinggi Kri(y)a Dalam Wahana Tradisi” Sebuah Tawaran Konteks. Pekan Pruduk Budaya Indonesia, Jakarta.

Ardana, Dewa Putu,2013, “Keben Di Banjar Tanggahan Peken, Bangli: Perspektif Kajian Seni) Program Pascasarjana Institut Seni Indonesia Denpasar, Denpasar.

Biakai Yufentius dkk. (2002), Asmat Mencerap Kehidupan Dalam Seni. (Terjemahan: Willie Koen) Drackhaus Cramer, Greven, Jerman.

Daniel, Pink H., 2006, Mesteri Otak Kanan Manusia, Think, Yogyakarta

Grace Cochrane, 1997," Keeping content: craft, history and curatorship", dalam Craft $a \quad n \quad d$ Contemporary Theory, Allen \& Unwin , Australia.

Hoop, Th. a Th. van der, 1949. Indonesische Siermotieven. N.V. Uitgeverij W. van Hove, Bandung, s'Gravenhage.

Mardiwarsito, L. , 1986, Kamus Jawa Kuna (Kawi) Indonesia, Nusa Indah, Flores NTT.

Surita Made, 1987, “ Seniman Payangan Tumbuh Subur Di Tengah Hutan Leci” Media Bali Post, Denpasar. 
Suparta, I Made dkk., Anyaman Daun Rontal Dan Ukir Kayu, Ngayah Majalah Aplikasdi Iptek, Vol. 8., Forom Layanan Iptek Bagi Masyarakat (Flifmas) Wilayah Bali. Denpasar

SP. Gustami, 1991 Seni Kerajinan Mebel Ukir Jepara: Kajian Estetika Melalui Pendekatan Multiisiplin, Kanisius, Yogyakarta.

....... , "Seni Kriya Indonesia Dilema Pembinaan dan Pengembangannya" (pidato Ilmiah pada Dies Natalis ke Tujuh, Institut Seni Indonesia Yogyakarta, Yogyakarta.

, 2007, Butir-Butir MutiaraEstetika Timur,Ide Dasar Penciptaan Seni Kriya Indonesia, Prasista, Yogyakarta.

Sutrisno Hadi, 1986, Bimbingan Menulis Skripsi Tesis, Jilid I. Yayasan Penerbit Fakultas sastra Psikologi Universitas Gajah Madha,Yogyakarta.

Tim Penyusun, 2016, Kamus Bali-Indonesia, Edisi Ke 3., Cet. Ketiga, Balai Bahasa Bali. Denpasar.

Tim Pemetaan, 2019, Pemetaan IKM Gianyar, Dinas Perindustrian dan Perdagangan Kabupaten Gianyar bekerjasama dengan Institut Seni Indonesia Denpasar, Dinas Perindustrian Kabupaten Gianya, Gianyar.

Winarno F. G., 1992, Rebung: teknologi Produksi dan Pengolahan, Pustaka Sinar Harapan, Jakarta

\section{NARA SUMBER}

Krisna I Made, Stap Perbekel Bukian, Payangan Wawancara: Tgl. 31 Agustus 2020

Rekin Ni Nyoman, Perajin Payung, Br. Subilang, Desa Bukian Kecamatan Payangan Wawancara : Tgl. 30 dan 31 Agustus 2020

Sudiarsa I Nyoman: Warga Masyarakat banjar Ata Batubulan, Wawancara Kamis, 20 Agustus 2020

Suwendra I Wayan, PJ. Perbekel Melinggih kelod Payangan, Wawancara Tgl. 12 Oktober 2019.

Teker I Wayan, Perajin Br. Subilang, Desa Bukian Kecamatan Payangan. Wawancara, Tgl. 14 Oktober 2019. 23 Agustus 2020., 26 Agustus 2020 